\title{
Analysis of High School Students' Social Skills on Online Learning During the Covid-19 Pandemic
}

\author{
Ira Lestari", Haryanto, Neni Aristya Sukmawati
}

\author{
Universitas Negeri Yogyakarta, Indonesia \\ *Corresponding author. Email: iralestari622@gmail.com
}

\begin{abstract}
The covid-19 pandemic has a significant impact on the learning system in schools, where learning is turned into online learning. Students learn to use more tools, and there is a very little interaction, thus making students' social skills different. The study aims to describe students' social skills in online learning during the pandemic. The method used is qualitative with percentage analysis techniques. The questionnaire data instrument was distributed to high school students in Jayapura City, and the student's responses were analyzed and presented in the form of percentages. The results of this study indicate that students meet the indicators of students social skills in online learning as much as $72.96 \%$. From these results, students' social skills in online learning during the pandemic is overall good.
\end{abstract}

Keywords: Students' Social Skills, Online Learning, Covid-19 Pandemic.

\section{INTRODUCTION}

Innovation in learning should be continuously developed by education and learning activists according to the demands of the times and certain situations. As is happening now, it started with a virus that emerged in Wuhan, China, around the end of 2019. Then on March 11, 2020, WHO officially announced COVID-19 as a global pandemic. This virus can be transmitted through droplets of human saliva, so the spread of this virus occurs very quickly. As such, COVID-19 prevention protocol requires social distancing to prevent transmission. The policy applies to all fields, including education, which affects the implementation of learning in schools.

So far, the learning system in schools uses the classical approach, namely face-to-face learning directly carried out in a room. Due to the social restriction protocol, this approach cannot be implemented anymore. Consequently, learning can only be carried out as an online learning. The online learning is chosen as a solution for implementing learning while still adhering to the rules of social restrictions to avoid covid-19. Online learning, in general, has a very different meaning from face-to-face or conventional learning. Online learning prioritizes aspects of accuracy, activeness, or foresight of students to receive, process and filter information submitted or presented through online media.

The differences between online and traditional learning systems force students and educators to adapt to the new system. Learning is usually done face-to-face in the classroom, making learning becomes more dynamic. It also can be done anywhere because the space used is a digital space in a network that can connect people from different places. However, the new learning system makes students no longer meet and communicate with peers or teachers.

Social distancing, as a policy to reduce the transmission of covid-19, limits social relations between students, which states that the COVID-19 pandemic impacts human needs as social beings who are constrained by physical distancing policies [1]. This can be seen in the current situation when children who usually study happily at school, meet and interact with teachers and friends, are now forced to study in unusual conditions, namely at home in a rather stressful atmosphere due to COVID-19.

The advantages of this online learning system are very helpful in maintaining effective and efficient learning and preventing the spread of the COVID-19 virus. Isman revealed that when learning activities are 
online, students have the flexibility of learning time because they can do learning anytime and anywhere [2]. However, online learning still had weaknesses, including achieving students' social competence. Afil (2020) revealed that learning activities affect the learning interest of SMPN 1 Satap Ladongi students because students get bored easily when online learning is carried out. Online learning is less interesting than learning in the classroom. Lack of material understanding may also occur in online learning.

Based on Bloom's taxonomy, there are three indicators of learning success, namely cognitive, psychomotor, and affective. Learning cannot be successful if it only meets the value of good knowledge because students must also be active and have noble character. Meanwhile, some previous studies mentioned, that some indicators show the weakening of students' social skills in online learning. Therefore, the purpose of this study is to describe students' social skills in online learning during the COVID-19 pandemic.

Social skills are the ability of individuals to perform certain actions that enable them to acquire social abilities. These skills include various linguistic and non-verbal, emphatic skills, problem-solving, expression of positive and negative emotions, and self-control [3]. This is supported by Kilic \& Aytar, which can improve social relations with the environment through empathetic behavior, participation in group activities, helping each other, communicating with others, negotiating, and solving problems. Thus, this social behavior is the basis for interacting with others and is one of the characteristics of an individual's positive and superior social skills [4]. On the other hand, Gumpel states that poor social skills can lead to loneliness, low social competence of children and, mental health problems to drug abuse. This can be seen in the current conditions, which indicate an increase in psychological disorders during the COVID-19 pandemic [5].

Online learning is very different from in-person learning. Students can interact socially with classmates and work together when studying in groups during their learning in the classroom. Meanwhile, when learning online, students only interact with friends or teachers through the help of media with networks. Learning is more often one-way, such as the teacher providing material and assignments, then students working on and collecting them. Some do virtual face-to-face learning using platforms such as zoom or google meets or elearning built by schools. However, it still has several obstacles, such as a weak network and inadequate facilities.

Educational Psychologist and Founder of Yaa BuNayya Pre-School Yogyakarta, Monika Aprianna, M.Psi.
[6] said that online schools are different from face-to-face schools. In face-to-face schools, all five senses are involved in the learning process. Meanwhile, when faced with online conditions, the process is now limited to only the screen, thus maximizing the sense of sight more than others. So, the possibility of children's skills will be lower. Students' social skills can be seen through several aspects. As explained by Caldarella and Merrell, five aspects of social skills for children and adolescents include [7]:

a. Peer relations (peer relationship skills), behaviors that show positive relationships with peers including favorable behavior, empathy, social participation, sociability leadership, kindness, active participation in discussions, peers communication skills.

b. Self-management skills, namely the individual's ability to self-regulate, including self-control, social independence, social competence, social responsibility, ability to make appropriate compromises with others, communicating and cooperating with others.

c. Academic skills, namely individual abilities that support learning achievement, include adjusting to the school environment, respecting school rules, understanding materials, listening and carrying out instructions from teachers, asking for help appropriately, task orientation and academic responsibilities.

d. Compliance skills, namely the individual's ability to fulfill the requests of others, including cooperation, relationships with friends/others, adjustment to others, completing tasks on time, following instructions, and obeying regulations.

e. Assertive behavior (Assertion skills), namely behavior dominated by abilities that allow individuals to display appropriate behavior in expected situations, including initiating conversations, assertiveness, social initiation, social mobilization, asking questions, and being brave.

This article is based on one argument, that online learning that is carried out with very limited interaction may weaken students' social skills. So, this research is important to describe the social skills of high school students, especially in Jayapura City during online learning in the COVID-19 pandemic, and to describe the coping strategy when facing technical obstacles such as network disturbances and inadequate learning facilities. The results can be used as a reference in developing high school learning in Jayapura City.

\section{RESEARCH METHOD}

This type of research used is a qualitative descriptive method. This method is used because in examining the problem, the author does not prove or reject the hypothesis that was made before the research, but processes data and analyzes a problem non-numerically [8]. 
This research was conducted in one of the cities in eastern Indonesia, namely the city of Jayapura. the informants in this study were 208 students from public and private schools. Two schools were involved, namely SMAN 4 Jayapura and SMA Muhammadiyah Jayapura
City. Data was collected using a questionnaire technique via google form. The questionnaire guidelines were made based on the five indicators of social skills of students from Cardarella and Merrel which were poured into a questionnaire grid as seen in Table 1.

Table 1. Questionnaire Grid

\begin{tabular}{|c|c|c|c|}
\hline No & Indicator & Sub Indicator & Item \\
\hline \multirow{2}{*}{1} & \multirow{2}{*}{ Relationships with peers } & Demonstrate an attitude of discussing with peers during online learning & 5 \\
\hline & & Demonstrate the attitude of helping peers when learning online & 7 \\
\hline 2 & Self-Management & Shows the attitude of communicating with others when learning online & 3 \\
\hline \multirow{2}{*}{3} & \multirow{2}{*}{ Academic Ability } & $\begin{array}{l}\text { Shows the attitude of listening to the teacher's explanation when learning } \\
\text { online }\end{array}$ & 1 \\
\hline & & $\begin{array}{l}\text { Demonstrate an attitude of understanding the material when learning } \\
\text { online }\end{array}$ & 4 \\
\hline \multirow{3}{*}{4} & \multirow{3}{*}{ Obedience } & Shows the attitude of submitting assignments on time & 8 \\
\hline & & Demonstrate an attitude of obeying the rules when learning online & 9 \\
\hline & & $\begin{array}{l}\text { Demonstrate an attitude of obeying the rules of virtual meeting when } \\
\text { learning online }\end{array}$ & 10 \\
\hline \multirow{2}{*}{5} & \multirow{2}{*}{ Assertif behavior } & Showing the courage to ask questions when learning online & 2 \\
\hline & & Shows the attitude of daring to interact during online learning & 6 \\
\hline
\end{tabular}

\section{RESULT AND DISCUSSION}

From the literature, the impact of the pandemic on the abilities of high school students so far tends to see two possibilities, the pandemic has weakened students' cognitive abilities and has separated students from social reality. The direct impact of switching systems or learning styles directly to online is the disruption of students' cognitive development due to boredom. In line with this, Wulandari (2020) mentioned that there is a phenomenon of high school students in East Jabung City, Jambi province who tend to have an attitude of procrastinating when learning online [10]. The pandemic has separated students from social reality, as can be seen in Annisa's research (2020) which explained that students have a very low ability to provide appropriate feedback during learning due to a lack of student understanding of the material. The majority of students today have become quiet humans because in learning during a pandemic, students tend to be more passive in interacting with teachers and peers [11]. Rizqon (2020) explained that online learning impacts students' psychological and social skills. The process of forming students' social skills experiences obstacles because social interaction can only be done through social media without any physical contact.

In this study, the results of a closed questionnaire referring to the social skills indicators from Cardarella and Merrell showed that $72.96 \%$ of students met the social skills indicator in online learning during the pandemic. The following is a description of the analysis of students' social skills in online learning during the pandemic: a. Students meet the indicators of relationships with peers as much as $67.74 \%$, discuss with peers during online learning as much as $68.65 \%$ and show an attitude of helping peers during online learning as much as $66.82 \%$ (Figure 1).

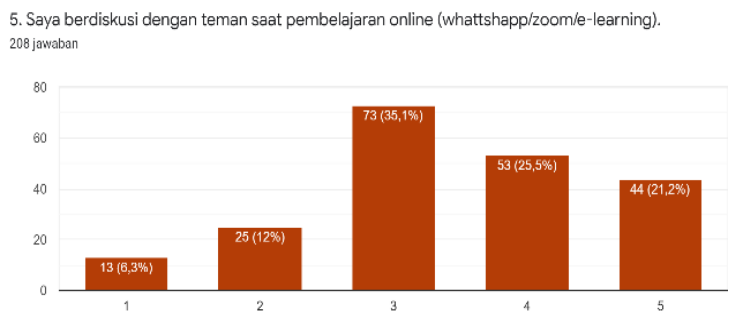

Figure 1 Response to statement number 5

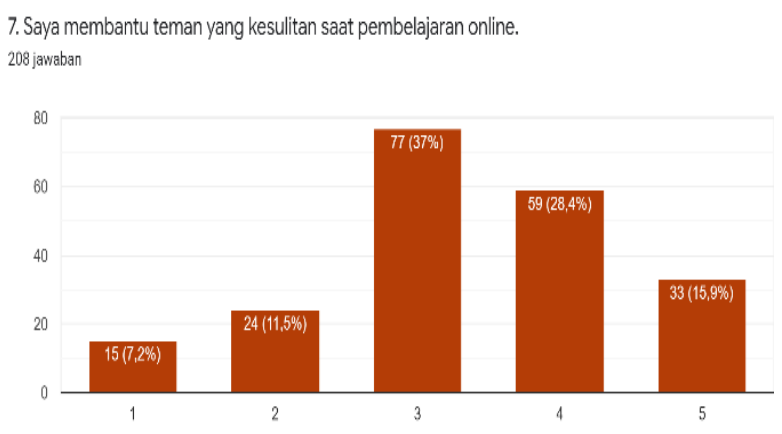

Figure 2 Response to statement number 7

b. Students meet the self-management indicator, communicating with others during learning is as 
much as $77.11 \%$. The results of the student's social skills response on the self-management indicator are illustrated in Figure 3.

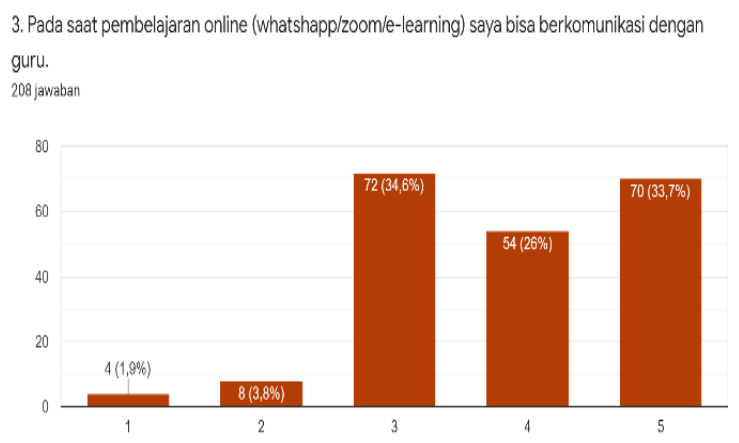

Figure 3 Response to statement number 3

c. A total of $76.49 \%$ students meet the indicators of academic skills when learning online with showing an attitude of listening to the teacher's explanation as much as $82.78 \%$ and showing an attitude of understanding the material as much as $70.19 \%$, as shown in Figure 4.

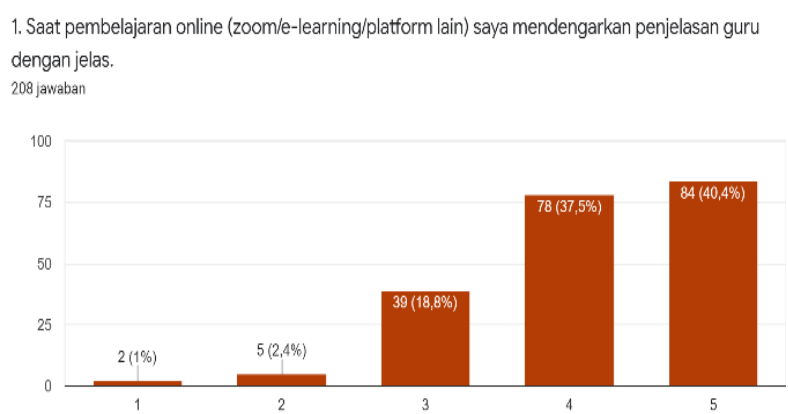

Figure 4 Response to statement number 1

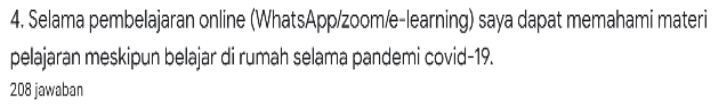

$$
208 \text { jawaban }
$$

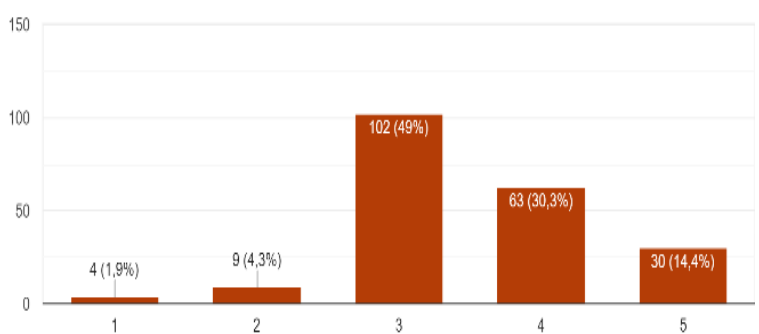

Figure 5 Response to statement number 1 d. Students who meet the compliance indicator as much as $84.83 \%$, showing an attitude of collecting assignments on time as much as $79.03 \%$, participating in online learning according to the schedule as much as $87.88 \%$ and showing an attitude of obeying the rules during virtual face-to-face learning as much as $87.59 \%$, as seen in Figure 6.

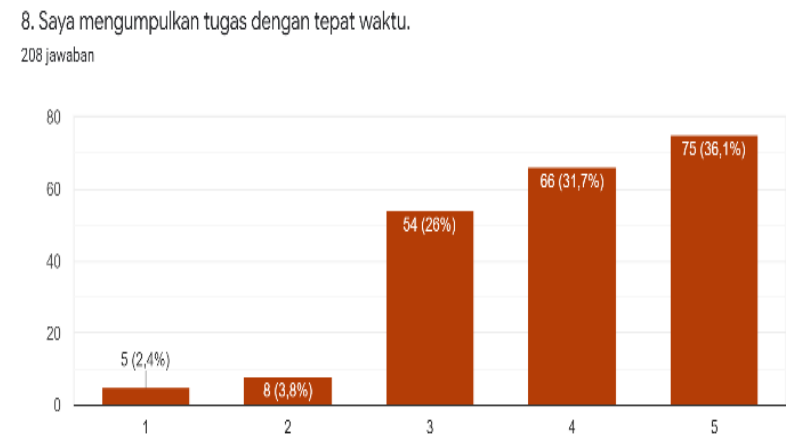

Figure 6 Response to statement number 8

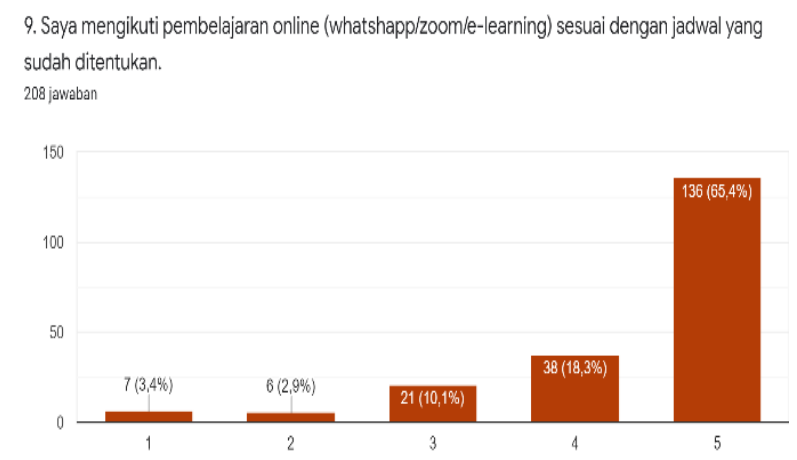

Figure 7 Response to statement number 9

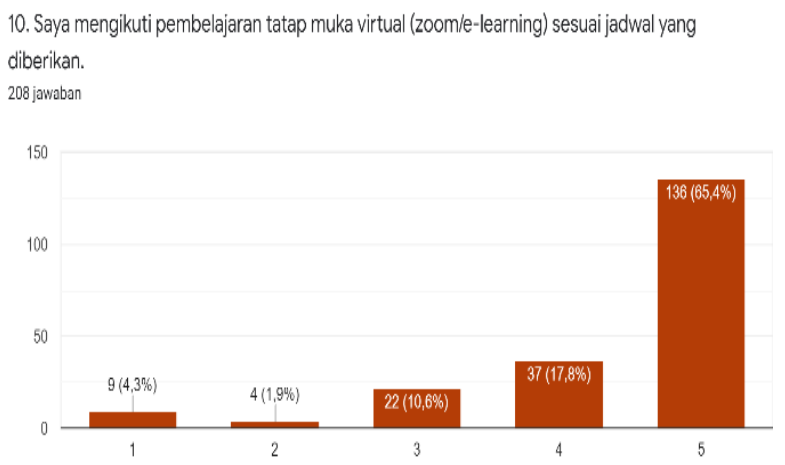

Figure 8 Response to statement number 1

e. Students meet the indicators of assertive behavior as much as $58.65 \%$, showing the courage to ask 
questions when online learning is $58.55 \%$ and showing the courage to interact during online learning as much as $58.75 \%$.

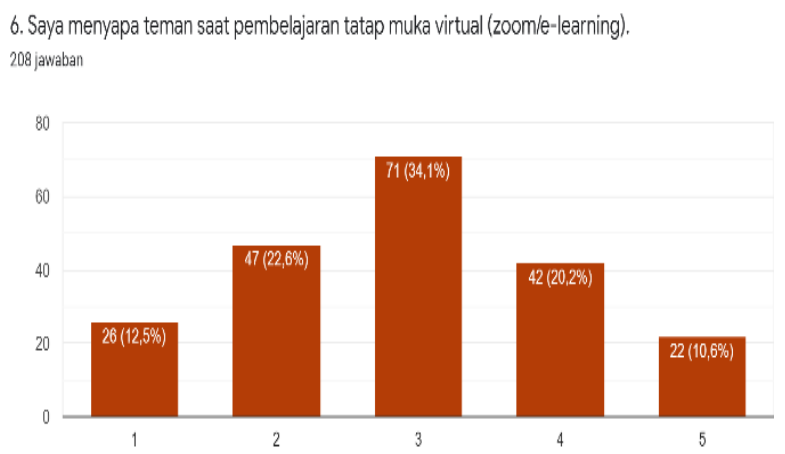

Figure 9 Respone to statement number 6

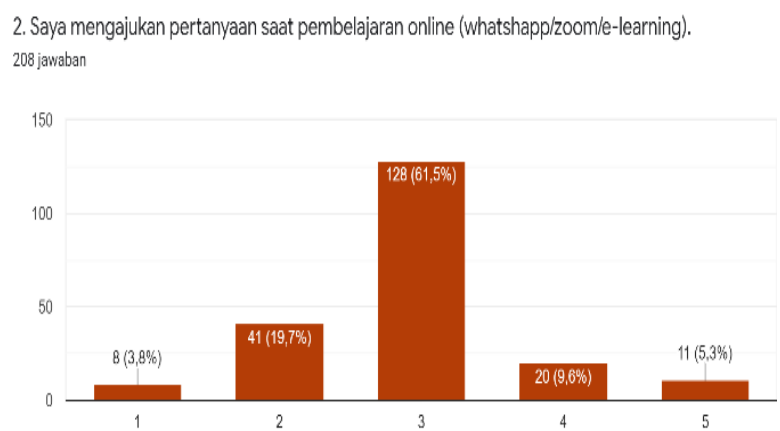

Figure 10 Response to statement 10

From the data obtained based on several indicators, it can be seen that the indicators of students' social skills during online learning are generally met in a fairly good category. However, if we look in more detail, students have higher percentages on academic skills and obedience indicators, while for indicators of peer relations and assertive behavior, they are lower. This is in line with the statements given by several teachers that online learning still has many shortcomings and obstacles. There are still students who do not have the tools to carry out online learning, such as computers/laptops, and some even do not have smartphones. The teacher also admits that there are difficulties in facilitating students to achieve their affective competence because of the limited interaction during an online learning.

\section{CONCLUSION}

It can be concluded that as many as $72.96 \%$ of students meet the five indicators of students' social skills when learning online. The five indicators are: peer relations, self-management, academic ability, compliance, and assertive behavior. Barriers to students during the online learning process that are found, such as students are still adapting to the current learning environment, internet network problems, and the role of teachers and parents is still not optimal.

\section{REFERENCES}

[1] R. D. Wiresti, Analisis Dampak Work from Home pada Anak Usia Dini di Masa Pandemi Covid-19. Jurnal Obsesi: Jurnal Pendidikan Anak Usia Dini, Vol. 5(1), pp. 641. DOI: https://doi.org/10.31004/ obsesi.v5i1.563

[2] W. A. F. Dewi, Dampak Covid-19 Terhadap Implementasi Pembelajaran Daring di Sekolah Dasar. Edukatif: Jurnal Ilmu Pendidikan, Vol. 2(1), 2020, pp. 55-61.

[3] M. L. Marinho, \& Casanova. Environmental influence on the development of social skills in children. Extensio: Revista Eletrônica De Extensão, Vol. 14(26), pp. 2-11. DOI: https://doi.org/10.5007/ $1807-0221.2017 \mathrm{v} 14 \mathrm{n} 26 \mathrm{p} 2$

[4] K. M. Kiliç, \& F. A. Güngör Aytar, The effect of social skills training on social skills in early childhood, the relationship between social skills and temperament. Egitim ve Bilim, Vol. 42(191), pp. 185-204. DOI: https://doi.org/10.15390/EB. 2017.7162

[5] K. Y. Sarnelle, Teacher Perspectives on Social Thinking. Rowan University, 2018.

[6] DetikHealth. Keterampilan Sosial yang Tercederai Sekolah Online (detik.com), 2021.

[7] A. Purnama, Optimalisasi Keterampilan Sosial ABK Melalui Metode Bermain Kooperatif Pada Paud Inklusi. Prosiding SNasPPM, Vol. 1(1), 2017, pp. 39-46

[8] Sugiyono. Metode penelitian kuantitatif, kualitatif, dan R\&D. Bandung: Alfabeta, 2016.

[9] I. Ernawati, Uji kelayakan media pembelajaran interaktif pada mata pelajaran administrasi server. Elinvo (Electronics, Informatics, and Vocational Education), Vol. 2(2), 2017, pp. 204-210.

[10] H. Wulandari, \& E. Purwanta, Pencapaian Perkembangan Anak Usia Dini di Taman Kanakkanak selama Pembelajaran Daring di Masa Pandemi Covid-19. Jurnal Obsesi : Jurnal Pendidikan Anak Usia Dini, Vol. 5(1), 2020, pp. 452. DOI: https://doi.org/10.31004/obsesi.v5i1.62

[11] A. Windarti, Zaharah, G. I. Kirilova. "Impact of Corona Virus Outbreak Towards Teaching and Learning Activities In Indonesia.”, Jurnal Sosial dan Budaya Syar'i, 07, no. 03 2020, pp. 269-82. DOI: https://doi.org/10.15408/sjsbs.v7i3.15104. 